\title{
Empirical Genetic Algorithm Parameter Tuning Concerning the Synthesis of Combinational Logic Circuits
}

Joshua Ward

Follow this and additional works at: https://researchrepository.wvu.edu/etd

\section{Recommended Citation}

Ward, Joshua, "Empirical Genetic Algorithm Parameter Tuning Concerning the Synthesis of Combinational Logic Circuits" (2017). Graduate Theses, Dissertations, and Problem Reports. 6913.

https://researchrepository.wvu.edu/etd/6913

This Thesis is protected by copyright and/or related rights. It has been brought to you by the The Research Repository @ WVU with permission from the rights-holder(s). You are free to use this Thesis in any way that is permitted by the copyright and related rights legislation that applies to your use. For other uses you must obtain permission from the rights-holder(s) directly, unless additional rights are indicated by a Creative Commons license in the record and/ or on the work itself. This Thesis has been accepted for inclusion in WVU Graduate Theses, Dissertations, and Problem Reports collection by an authorized administrator of The Research Repository @ WVU. For more information, please contact researchrepository@mail.wvu.edu. 


\title{
Finding Booth: My Journey through Topdog/Underdog
}

\author{
Andra Ward Jr. \\ Thesis Submitted to the College of Creative Arts \\ West Virginia University \\ In Partial Fulfillment of the requirements \\ For the degree of \\ Master of Fine Arts in Acting
}

Radhica Ganapathy, PH.D.

Laura Hitt, MA

Irene Alby, MFA

School of Theatre and Dance

Morgantown, West Virginia

2018

Keywords: Topdog/Underdog, Suzan-Lori Parks, Acting, Booth, Black Plays, Masculinity (C) Copyright 2018 Andra Ward Jr. 


\section{Abstract \\ Finding Booth: My Journey through Topdog/Underdog Andra Ward Jr}

This thesis recounts my experiences during West Virginia University's Fall 2017 Production of Topdog/Underdog as the role Booth. The purpose of my thesis role was to utilize the training I received during my tenure at WVU, allow myself to be emotionally vulnerable, while sustaining my artistry within a 2-hour 2-person play. Utilizing Linklater, Meisner, and Chekhovian techniques proved fruitful in expanding my range as an actor. Ultimately, the results culminated into artistic, mental, and personal growth that has and will continue to broaden my capabilities as an actor. 


\section{Table of Contents}

INTRODUCTION

RESEARCH 5

Overall SynOPSIS 5

TEXT ANALYSIS

THEMES

FINDING Booth WITh My SELF

REHEARSAL 42

FIRST WEEK 42

SECOND WEEK

THIRD WEEK

FOURTH WEEK

53

FIFTH WEEK

PERFORMANCE

LEARNING OUTCOMES

FinAL THOUGHTS 


\section{Introduction}

Once upon a time, there was a guy who'd never heard of theatre. His predominately African-American schools, elementary to high school, did not offer any opportunities in theatre or drama, so being part of a show or even going to theatrical production was out of the question. He focused his sights on lucrative jobs within the medical field and attended a PWI for his postsecondary education. His life changed when his core curriculum required him to attend a theatre production for his Theatre Appreciation class. That life changing moment brought him to the point where theatre began consuming his daily activities, and he will now be graduating with a Masters in Fine Arts in Performance. You probably already guessed this cliché 'troupe is about me. And pause for laughter.

I've always felt like a late bloomer in terms of my introduction to acting. I was 22 when I started acting and realized I could not relinquish control to this acting bug; I needed a sign. In my very first acting class, which I only took out of a losing bet with a friend, I discovered and fell in love instantaneously with Topdog/Underdog and its themes of poverty, brotherhood, loyalty, and familial crises. I decided to perform a scene from Topdog/Underdog since I had an immediate personal connection. With the success of my scene, my acting teacher encouraged me to audition for the next show and the rest was history.

Although I initially had a visceral reaction to Topdog/Underdog, I didn't realize how much I truly loved it until I read other plays prescribed from theatre history teachers. I learned fast that African American characters within canonical plays were limited. Black actors are limited to Othello, Aaron the Moor in Titus Andronicus, The Wilson Cycles, and sometimes Clay from the Dutchman. Opportunities to play in a production of these characters are few and far between. It became discouraging to have to always consider race in the audition/casting process. 
Will I be cast in this role based on talent or by the color of my skin? In academic theatre, it became even more frustrating for issues of race because it seemed to conveniently disappear after casting was done. Was I cast in this role because of my skin color? Does my race automatically brand me to a specific type? I never truly found the answer to these questions. To make matters worse, costume renderings often happen before casting, so I've frequently encountered renderings that portrayed a white actor. [Really, you did not have enough time to change the color of the skin] I guess I should be grateful for the opportunity and not worry too much about details. Fortunately, Topdog/Underdog made it through the cracks. I did not have to worry about my race during casting.

Topdog/Underdog by Suzan-Lori Park, premiered July 26, 2001. Directed by George C. Wolfe, Don Cheadle played Booth and Jeffrey Wright played Lincoln. The successful run of the show earned a Pulitzer Prize for Drama in 2002 along with a number of awards and nominations. I was shocked to learn of its success. The urban language used by Parks could potentially be alienated with certain crowds. She proves relentless in her pursuit for authenticity by pushing the envelope with the language of the play. With terms like "Cracker-ass white man" and various obscene words, it runs the risk of deterring conservative white audiences, distracting from the plot, and offending morals. Luckily, she exploits universal themes. She explains during an interview with Ronni Reich in 'Togdog/Underdog': A playwright interpreting her own words:

I think the meaning of the play isn't just confined to a man's experience. I think it's about what it means to be family and, in the biggest sense, the family of man, what it means to be connected with somebody else. And if you've thought about the American dream, this play might speak to you. If anyone ever told you, 'You're going to be such and such way when you grow up,' or you thought, 'I'm 
turning into my mother,' this has something to say to you. ... You might have moved out of the house when you were 18, but you carry your family situation around with you. (Reich)

The success for any story is its ability to connect with its audience. Nonblack patrons may initially feel the play is unrelatable. Nevertheless, Parks is a black playwright. Most would argue she only write black plays. In Basic Black, Nadine George-Graves claims that "Black Theatre, black drama, black plays have been a ghetto to some, a haven to others" (Graves 611). For me, it is definitely a haven. I feel as if I can express a voice that is usually suppressed in theatre.

So you can understand how ecstatic I was when WVU announced that Topdog/Underdog would be part of the 2017/2018 season. This was on my bucket list of dream plays. And to be honest, due to the cast size, I always thought it was unlikely for it to be produced or rather for me to be cast in it. Luckily, I was offered the role of Booth, with the added bonus of including a guest director. I lived within this delightful bliss as an accomplishment that would never be taken away for me. So, yes, of course, I decided this role would serve as my thesis role.

As part of my requirements for my thesis, I needed to write about my process. I concluded that this thesis would be slightly informal in order to authentically capture my journey in finding my character, Booth. Below will serve as a road map/blueprint for this endeavor:

Research-This section will include a brief synopsis, a detailed plot synopsis, text analysis, and themes.

Rehearsal-This section will be a week by week account of my rehearsal process. Performance-This section will include a general assessment of the run including mishaps. 
Evaluation-This section will include a review of the run, my work, as well as learning outcomes from this experience.

I am determined to openly and candidly convey each aspect that played a part in bringing together this powerful and moving show. I came to WVU with insecurity about my abilities, but I can honestly say, my training at WVU allowed me to articulate my transformational journey into a confident actor. 


\section{Research}

\section{Overall Synopsis}

Set in the late 90s, Topdog/Underdog by Suzan Lori Parks follows the lives of Lincoln and Booth. Lincoln, down on his luck, lives in Booth's small cramped studio apartment. The apartment lacks running water, a bathroom, and a kitchen. Stricken with poverty at a young age after their parents abandoned them, Lincoln and Booth find themselves trapped in a vicious cycle of poverty time and time again. Lincoln acts as sole provider to the household. Unfortunately, he works as an Abraham Lincoln impersonator who enacts the final moments of his death via an assassination. Every week he earns a measly $\$ 300$ to make ends meet. Times are tough and tensions are high.

Booth concocts a plan. He tries to convince his brother, who was once "a great hustler," to return to a card game called 3-Card Monte. Lincoln avoids returning to this fast life. He never really recovered from the loss of his best friend, Lonny, causing a domino effect that made him quit his hustle, lose his wife, and take on a demeaning job. Stuck in his woes, he prevents his brother from joining that lifestyle. Booth, on the other hand, looks up to his brother and wants to change this rut they have found themselves in. Not to mention, he has a girlfriend that he loves and wants to impress. A chain of events trigger Lincoln's tragic and expected demise at Booth's hand. 


\section{Text Analysis}

Act 1 Scene 1

\section{Synopsis}

Booth practices 3-Card Monte. Lincoln walks in on him wearing his work uniform, a complete replica of Abraham Lincoln including whiteface, scaring Booth. Booth takes out his gun and points it at Lincoln. Booth demands that Lincoln takes off his work uniform. Lincoln works at an arcade where he enacts the assassination of Abraham Lincoln; customers take turns shooting him. Booth withdraws his gun and brags about being back with his ex-girlfriend, Grace. Dressed like Abraham Lincoln, Lincoln finally complies and talks about his journey home on the bus. He describes how he hustled a young rich kid. Lincoln and Booth laugh at the young kid's misfortune. Booth, riding the hype, shows off what he's being doing all day. Booth creates a "modular unit" that serves as a dining table and bookshelf. Booth continues to tell Lincoln that he changed his name to "3-Card". Lincoln makes fun of the new name, but accepts it. They soon argue about who puts the food on the new table. They both take low blows. Booth talks about Lincoln's divorce and homelessness; Lincoln talks about Booth's poor apartment that has no running water, toilet, or sink. Lincoln serves the food. During and after the meal, Booth tries to convince Lincoln to play 3-Card Monte. Lincoln firmly says no and the two argue again. They each go to their respected spot in the apartment. Lincoln brings up their father and how he joked about their names. They bond then go to sleep.

\section{Analysis}

The show opens with Booth practicing his 3-Card Monte moves. We take note that he is pretty boisterous and loves to brag even when he is alone. While throwing the cards, he's proud 
of his mantra, "3-card-throws-the-cards-lightning-fast.3-card-that's-me-and-Ima-last." It is clear he likes to be the center of attention no matter what the circumstances may be. Booth's showboating attitude increases even more so when his brother, Lincoln, enters the room:

I got a date with Grace tomorrow. Shes in love with me again but she don't know it yet. Aint no man can love her the way can...I got her this ring today. Diamond. Well, diamond-esque, but it looks just as good as the real thing. Asked her what size she wore. She say 7 so I go boost a size 6 and a half, right? Show it to her and she loves it and I shove it on her finger and it's a tight for so she can't just take it off on a whim, like she did the last one I gave her. Smooth, Right? (14)

Here we see Booth's swagger being undercut by his need of approval from Lincoln. He wants to gloat about his dating mastery, unfortunately, Booth wants approval from his older brother. Booth always wanted to be like his older brother. He idolized his brother so much that he wants his brother to recognize him as a man worth running the streets with him. So Booth learns how to throw the cards like him. The name of the game: 3-Card Monte. To clarify, 3-Card Monte is a game where the dealer shuffles 3 cards and the participant must pick out the right card. In his heyday, Lincoln was known to be superior for throwing cards or shuffling effectively. Men wanted to be him and women wanted to be with him. All the things Booth strives to emulate. However, prior to the opening of this play, Lincoln decided to stop throwing the cards. To prove his worth, Booth constantly practices throwing the cards like his brother all while trying to convince his brother to go back to his hustling days.

Initially, Booth tries to hide that he has been practicing throwing the cards. He does not do a good job. Lincoln questions if he's been playing card. Booth is eager to play the game with 
him and show off his skills. Booth goes so far as to change his name to 3-card in order to impress his brother:

\section{BOOTH:}

My new names 3-card. 3 card, got it? You wanted to know it so now you know it. 3-card monte by 3-card. Call me 3-card from here on out.

\section{LINCOLN:}

"3-card." Shit.

BOOTH"

Im getting everybody to call me 3-card. Grace likes 3-card better than Booth. She says 3-cards got something to it. Anybody not calling me 3-card gets a bullet.

\section{LINCOLN}

Yr too much, man.

\section{BOOTH}

Im making a point.

\section{LINCOLN}

Point made. 3-card, Point made.

\section{BOOTH}

Oh, come on, man, we could make money you and me. Throwing down the cards. 3-card and Link: look out! We could clean up you and me. You would throw the cards and I'd be yr Stickman the one in the crowd who looks like just an innocent passerby, who looks like just another player, like just another customer, but who gots intimate connections with you, the Dealer, the one throwing the cards, the main man. I'd be the one who brings in the crowd. I'd be the one who makes 
them want to put they money down, you do yr moves and I do mines. You turn yr head and I turn the card-

\section{LINCOLN}

It aint as easy as all that. Theres-

\section{BOOTH}

We could be a team, man. Rake in the money! Sure thered be some cats out there with fast eyes, some brothers and sisters who would watch real close and pick the right card, and so thered be some days when we would lose money, but most of the days we would come out on top! Pockets bulging, plenty of cash! And the ladies would be thrilling! (24)

Staying true in nature, Booth tries to convince his brother to throw the cards again. Booth has the same conviction as he does in the opening monologue, full of high contagious energy. Booth is poor. He needs this new hustle to change his status. He's clearly been pondering over the bestcase scenario for years and wants to let his brother in on the plan. He recognizes the situation the two of them are in and even tempts the recent divorcee with finding him a girlfriend. Nonetheless, Lincoln is unbothered by his attempts.

Lincoln's rejection affects Booth immensely. Tenacious Booth does not stop there. He brings up their mom's departure. Booth paints the picture of her putting all her belongings in "plastic bags" with her last words being, "to look out for[Lincoln]." These last words baffled Booth because he felt like his brother should look out for him. So when the situation arises where Booth feels like he's looking out for Lincoln, he remains conflicted: 
So who gonna look out for me. Not like you care. Here I am interested in an economic opportunity, willing to work hard, willing to take risks and all you can say you shiteating motherfucking pathetic limpdick uncle tom, all you can tell me is how you don't do no more what I be wanting to do. Here I am trying to earn a living and you standing in my way. YOU STANDING IN MY WAY, LINK. (26)

This is the first time we see Booth's emotion get the best of him. He approaches Lincoln with an opportunity and ends up being upset with Lincoln. When upset, Booth holds no punches and becomes cut throat. These insults to Lincoln hinder his ability to persuade him to join him in his plan especially since Lincoln never insulted Booth. Their argument concludes with Booth telling Lincoln he needs to move out.

Lincoln sings a bluesy song that reflects his current situation to break the tension in the room. He then uses their father to get back in better graces with Booth. Booth, although close to their mother, was never close to their father. Booth always wanted to know what their father was like. Lincoln knows this and takes advantage of this fact. Lincoln reminisces on a conversation he had with their father:

\section{LINCOLN:}

Daddy told me once why we got the names we do. BOOTH:

Yeah?

LINCOLN:

Yeah. (rest) He was drunk when he told me, or maybe I was drunk when he told me. Anyway he told me, may not be true, but he told me. Why he named us both. Lincoln and Booth. 


\section{BOOTH:}

How come. How come, man?

\section{LINCOLN}

It was his idea of a joke. (both men relax back as the lights fade) (29)

The tension in the room escapes and the brothers reflect on what their father meant. This blatant foreshadowing seems to suffice for Booth since he had no follow up question. We are left with knowing the ending of the play but not the journey.

Act 1 Scene 2

\section{Synopsis}

'Next day', Booth enters in showing what he's done all day: Stealing. Booth takes off his person's two pairs of pants, two suit jackets, two shirts, two ties, two belts, a bottle of alcohol, and a "fuck book." He later goes back in the hallway and brings a portable wall or partition. He then begins to start enjoying his "fuck book" before he is interrupted by his brother. Lincoln comes in with excitement because today was payday. Lincoln and Booth perform their payday ritual. Booth shares his good news as well and shows off the new suits. Booth tells him that one of the suits belong to him. They try on the suits and walk around the apartment with swagger. Booth states that he will wear his suit to his date with Grace tonight. Lincoln then tells Booth to count the money. Booth counts the money and budgets it out leaving Lincoln \$14 out of \$314. Lincoln complains about how much money he is receiving and that his job may try to replace him with a wax dummy. Booth shrugs it off and asks about Lincoln's best customer. They bond and share a laugh. Lincoln says that he doesn't want to lose his job. Booth suggest that he "jazz up his act." Lincoln agrees and asks Booth to help him. However, Booth needs to go on his date. Booth tells Lincoln he will help him once he gets back. Lincoln puts on his getup and practices 
his routine implementing Booth's advice. Lincoln, uninspired by the results, starts to drink and passes out in his recliner.

\begin{abstract}
Analysis
The scene opens with us witnessing the true talents that Booth has: stealing. He stole two suits (One for him and one for Lincoln), a bottle of liquor, and a magazine; he carried these items under his jacket, another example of his ingenuity. He carefully places all the items in the room on display for when his brother comes home. When Lincoln brings home the money, they celebrate their payday. In turn, Booth wants the same celebration for his stealing, but his brother doesn't notice the array laid out in front of him. Booth gets upset:
\end{abstract}

\title{
BOOTH:
}

You rush in here and dont even look around. Could be a fucking A-bomb in the middle of the floor and you wouldn't notice. Yr wife Cookie-

\section{LINCOLN:}

Ex wife

\section{BOOTH:}

Could be in my bed you wouldn't notice-

\section{LINCOLN}

She was once-

\section{BOOTH}

Look the fuck around please. (31)

Once again, Booth looks for his brother's approval and praise. And once again, when he doesn't immediately get it, he lobs insults to get what he wants. Booth portrays a typical younger brother anytime this pattern is present. Luckily, he's gets what he wants when Lincoln's says, 
"You all right, man." Booth feels proud to hear these words from his brother. He does not hear them often. Lincoln's acknowledgement of Booth allows for the two to strut playfully around the apartment with their new suits. The brother's bond over their sharp appearance.

After the strutting, Booth counts the money. This is their typical ritual on payday. Lincoln brings home the money and Booth manages it. Booth is the housemaker. He cleans and maintains the home as well as budgets their expenses. Lincoln has no voice when it comes to these matters. Even when Lincoln wants to save money by not having a phone, Booth rationalizes why they need one:

How you gonna get a woman if you dont got a phone? Women these days are more cautious, more whaddacallit, more circumspect. You go into a club looking like a fast daddy, you get a filly to give you her numerophono and gone is the days when she just gives you her number and dont ask for yrs.... She gives you her number and she asks for yrs. You give her yr number. The phone number of yr home. Thereby telling her 3 things: 1.) you got a home, that is, you aint no smooth talking smooth dressing homeless joe; 2) that you is in possession of a telephone and a working telephone number which is to say that you got thuh cash and thuh wherewithal to acquire for yr self the worlds most revolutionary communication apparatus and you together enough to pay yr bills?...[3.)] You give her yr number you telling her that its cool to call if she should so please, that is , that you aint got no wife or wife approximation on the premises. (Rest) $\$ 50$ for the phone leaving \$134. (36-37) 
Booth gets what he wants. Booth's reconnection with Grace prompts him to want the phone so she can call him. And in turn, it could prove beneficial for Lincoln's love life. Booth also uses this opportunity to prove he's a man by showing off his "playboy" skills in the art of dating. Booth likes to feel like he is "dropping knowledge" on his older brother. All of which, boosts his confidence.

Once Booth situates the budget, Lincoln opens up about his job making cutbacks. Booth is too busy getting ready for his date tonight. He initially reflects Lincoln's concerns by suggesting that he return to throwing the cards again. Booth recognizes that this is still not an option for Lincoln and tries to give him advice:

You gotta jazz up yr act. Elaborate yr moves, you know. You was always too stiff with it. You cant just sit there! Maybe, when they shoot you, you know, leap up flail yr arms then fall down and wiggle around and shit so they gotta shoot you more than once. Blam Blam Blam! Blam! (40)

Similarly, to the previous insert, Booth gives advice in a manner that seems helpful, but at the expense of insulting Lincoln. Booth throws this suggestion in passing as he exits out the door for his date with Grace. Lincoln asks for help, but Booth denies it. Booth not only squashes Lincoln's cry for help but also confidently asks for more money. Booth knows he will get money from Lincoln. This interaction further solidifies Booth as the self-centered younger brother. 
Scene 3

\section{Synopsis}

Much later that night, Lincoln jolts up, notices Booth isn't home and goes back to sleep. Booth enters the apartment. Booth wakes up Lincoln and starts to brag about his date with Grace. Booth gets ready for bed because Grace "wore him out." Lincoln asks Booth to help him with his Abe Routine. Booth denies him. Lincoln calls Booth out about lying about his date. The two argue about their sexual prowess. Feelings are hurt and they go to their separate areas. Time passes. Lincoln breaks the silence by suggesting that Booth, or 3-Card, could hustle the cards with his help and connections. Booth claims he already knew that and asks Lincoln if he feels like someone would gun him [Lincoln] down in real life. Lincoln does not think he has enemies so he brushes off the notion. Booth examines Lincoln's work life. Lincoln elaborates on how his routine is typically performed and complains about cut backs. Booth offers to help. They work together to perfect his act. When Lincoln's death looks a little too real, Booth stops the exercise. Lincoln gets upset stating that he's done with the cards and this job is all he's got. Lincoln accuses Booth of trying to get him fired. Booth only wants to help, however if he was to get fired, he reassures Lincoln that they could work and support each other with cards. Booth realizes that Lincoln will not budge on the idea of staying away from the cards. Booth asks Lincoln for the last trick of the 3-Card hustle. Lincoln adamantly tells him no and goes to bed. Booth watches him doze off, places a blanket over Lincoln and goes to bed.

\section{Analysis}

Booth proudly struts into the apartment from his date. He intentionally wakes his brother up so that he can brag about his date. Not concerned with Lincoln's current drunken state, he speaks boastingly and triumphantly about his romantic date with Grace: 
Grace Grace Grace.Grace. She wants me back. She wants me back so bad she wiped her hand over the past where we wasn't together just so she could say we aint never been apart. She wiped her hand over our breakup. She wiped her hand over her childhood, her teenage years, her first boyfriend, just so she could say that she been mine since the dawn of time...We was over at her place. I brought thuh food. Stopped at the best place I could find and stuffed my coat with only the best. We had the music we had the candlelight we had--(42-43)

This is a direct reflection of the first scene: Booth bragging about stealing something and using it to court Grace. Lincoln, for the first time, plays into Booth's behavior, "She walks on by and the emergency room fills up cause all the guys get whiplash from lookin at her...She let you do it?"(44) Booth confirms they had sex with vulgar details. Skeptical, Lincoln allows him to continue to talk about Grace at lengths. Booth describes how " shes making something of herself. Studying cosmetology... She got this way of sitting. That. Everything she does is. Shes just so hot" (47). Booth then reveals she broke up with him because he was unemployed and she needed time to think. Luckily, after this date, she's done thinking. Booth, tired from his night, tries to go to sleep.

At this point, Lincoln is ready to practice his moves like Booth promised. Booth clings to his thought of Grace and does not want to help Lincoln now. Lincoln calls out Booth, "You laying over there yr balls blue as my boosted suit. Laying over there waiting for me to go back to sleep or black out so I wont hear you rustling thuh pages of yr fuck book"(49). Lincoln hasn't believed Booth this entire time that Booth had been boasting about Grace. Lincoln played along with Booth's charade to get help with keeping his job. When that didn't work, he hits below the belt. In turn, Booth lashes back with a lengthy monologue: 
Im hot. I need constant sexual release. If I wasn't taking care of myself by myself I would be out there running around on thuh town which cost cash that I don't have so I would be doing worse: I'd be out there doing who knows what, shooting people and shit. Out of a need for unresolved sexual release. Im a hot man. I aint apologizing for it. When I don't got a woman, I gotta make do. Not like you, Link. When you dont got a woman, you just sit there. Letting yr shit fester. Yr dick, if it aint falled off yet, is hanging there between yr legs, little whiteface shriveled-up blank shooting grub worm. As goes thuh man so goes thun mans dick. Thats what I say. Least my shits intact. (rest) You a limp dick jealous whiteface motherfucker whose wife dumped him cause he couldnt get it up and she told me so. Came crawling to me cause she needed a man. (rest) I gave it to Grace good tonight. So goodnight.(49-50)

Booth brings up quite a few things during his fit of anger. For starters, he explains how, if unchecked, his sexual drive could lead him to shoot someone. Here we have another possible foreshadowing device placed by the playwright that helps support their birth names. He then goes on to attack Lincoln's sexual prowess, supporting the known claim 'if you don't use it, you will lose it'. Booth bluntly says that Lincoln's impotence caused his ex-wife to have sex with him. He concludes with reiterating that he did in fact have sex with Grace. This shuts Lincoln down and they both go to their respective space in the apartment.

Lincoln breaks the long-tensed silence proving that he is the big brother. $\mathrm{He}$ encourages and suggests that Booth throws the cards himself. He offers his old crew and a possible game plan that will allow him to slowly build his reputation. Booth reluctantly 
gives in to Lincoln's conversation until Lincoln brings up having a gun. Booth boasts about how he knows more about guns than Lincoln. Lincoln rebuttals, "Im around guns every day. At the arcade." This leads Booth to ask Lincoln about his job and how it feels to have people shoot at him all day long. Lincoln eventually complies and gives a descriptive account of his typical day. Booth, moved by the story, offers to help him with his moves. Booth pushes Lincoln to have his death be more realistic. Booth tells him to scream, cuss, and move around. Unfortunately, the practice rounds began to look "too real" for Booth and he stops the practice sessions. That's the second time this scene foreshadows Lincoln and Booth's destiny.

Lincoln lashes out at Booth. Lincoln feels Booth is trying to get him fired so that he would throw the cards again. This time, Lincoln is not having it. Even though, this job is low paying and degrading Lincoln remains adamant that "Its a sit down job. With benefits." That's all Lincoln wants. This completely conflicts with what Booth wants. However, Booth is willing to settle as he pleads, "Just show me how to do the hook part of the card hustle man. The part where the dealer looks away but somehow he sees-[the card]" (58). Lincoln shuts down booth with a determined "No!" and goes to bed. Booth follows suit.

Scene 4

\section{Synopsis}

Lincoln wakes up in the middle of the night. He finds a cup to urinate in since there is no running water. He realizes that he fell asleep in his work outfit, which he hates doing. He starts talking to himself. He complains about his job, brags about how good at hustling he was, and how his best 
friend died while hustling. He sees the cards. They call him like a bad drug. Unable to resist their hold on him, he picks up the cards and plays. While Lincoln plays, Booth wakes up and sees him throwing the cards. Lincoln looks down, realizes how entranced the cards has him, and asks God for help.

\section{Analysis}

This scene focuses on Lincoln, providing insight about his life. Analyzing strictly from Booth's perspective, he has no lines, however, he wakes up towards the end of the scene. Booth has been convincing his brother to throw the cards again since the beginning of the play with no success. Booth gains hope when he sees his brother in his element. Hope that they would finally work together. Hope that their financial situation would get better. Hope for the future. Unfortunately, Booth falls asleep before Lincoln snaps out of his zone and asks God for help. The first act concludes with Booth being optimistic and Lincoln being pessimistic.

Act 2, Scene 1; Scene 5

\section{Synopsis}

'Several days passes.' Booth has been setting up for his date with Grace. He has the apartment to himself. There are new curtains, doilies, candles, champagne, spaghetti dinner, and a small jewelry box. Grace is late. Lincoln comes in drunk. He lost his job. Booth tries to get rid of him before Grace shows up. Lincoln tells Booth that he will leave when she gets there. Booth says ok and finishes getting ready. Lincoln breaks the silence and asks Booth if he remembers their parents' house. They reminisce on their childhood: their parents, their parents leaving, their 
inheritance. They joke about their parents starting a new family somewhere else. Booth admits that he was ok with this situation because his brother was there and, again, tries to convince Lincoln to show him how to throw the cards. Lincoln finally agrees. Lincoln breaks down the essentials of the throwing the cards. Booth starts to boast about how much he approved and talks trash to Lincoln. Lincoln tells Booth to calm down and pay attention. Too high off his skills, Booth ignores it. Lincoln tells Booth to throw the cards. Lincoln laughs at Booth's true skills at throwing the cards and brings up the past where Booth messed up a hustle and cost them $\$ 800$. Booth realizes that he is still waiting for Grace and asks for the time. Booth becomes irate due to it being past 3 a.m. Their date was scheduled for 8 p.m. Booth storms out saying that no one will make a "chump" out of him.

\section{Analysis}

This act opens with Booth waiting for his date with Grace. Let's discuss Booth's relationship with Grace. After being together for two years, Grace broke up with him. She took him back right before the play started because Booth stole a ring for her. They enjoyed "an evening to remember" the following day. And now, several days later, Booth clearly plans to recreate another romantic evening. In a true perfectionist fashion, Booth romantically decks out the entire apartment to impress her. He even dresses to impress. Booth is fully committed to propose to Grace the best way he knows how. Unfortunately, Grace is a no call no show. Why would she not call if she wasn't going to show up especially if Grace and Booth were in a better place. Has Booth been Lying about Grace? And Why?

In the midst of waiting for Grace, Lincoln drunkenly barges in the apartment after being fired from his job. Lincoln explains how they fired him as soon as he walked in the door. They 
even showed him the wax dummy. Booth, however, is more concerned with making sure that everything will be perfect when Grace finally comes. Booth brushes him off multiple times until he finally promotes, "Link. Yr free. Yr free at last. Now you can do anything you want...Graces on her way. You gotta go"(65). Lincoln jokes about how she is late and that he'll leave when Grace gets there. Booth allows him to stay. Lincoln brings up the past about their childhood home.

This is the only time we actually see Lincoln and Booth bond where money was not involved. "I was 4," Booth describes their childhood home, "Cement back yard and a front yard full of trash." Lincoln adds that they, "had some great times in that house." He reflects on a time where they lined up nails behind their Dad's car together. When their father found out, they never revealed that they were the ones who did it. Booth sentimentally finishes painting the picture of said event:

We was eating pork chops, mashed potatoes, and peas. I remember cause I had to look at them peas real hard to keep from letting on. And I would glance over at you, not really glancing not actually turning my head, but I was looking at you out thuh corner of my eye. I was sure he was gonna find us out and then he woulda whipped us good. But I kept glancing at you and you was cool, man. Like nothing was going on. You was cooooool. (rest) What time is it? (69)

Booth likes to reminisce on the past. He holds on to things that mean a lot to him. For example, he keeps up with their family photo album and likes taking pictures to put in the album. Lincoln knows this and thought it would be a good way to keep Booth preoccupied versus having Booth 
stress over Grace's appearance. It almost worked. Booth still worries about her coming. Lincoln notices that "[Booth] looks sad." Booth plays it off, "I'm cool" and changes the subject.

Booth asks Lincoln about his severance package. Lincoln states that he spent it all and it “felt good, spending it. Felt really good." Lincoln doesn't live in this euphoria long. He discusses with Booth the motive of their parents desertion. Lincoln felt like they were struggling with their own demons and tried to run away from them by moving to a house. And hopefully, those struggles would see their house and " be impressed and just leave them be." But things did not work out and they were abandoned at a young age. Booth, on the other hand, felt like they were grown at age 16 and 11 and that their parent's downfall is a life lesson:

They didn't leave together. That makes it different. She left 2 years go by. Then he left. Like neither of them couldn't handle it no more. She splits and then he splits. Like the whole family mortgage bills going to work thing was just too much. And I dont blame them. You don't see me holding down a steady job. Cause its bullshit and I know it. I seen how it cracked them up and I aint going there. (rest) It aint right me trying to make myself into a one woman man just cause Grace wants me like that. One woman rubber-wearing motherfucker. Shit. Not me. She gonna walk in here looking all hot and shit trying to see how much she can get me to sweat, how much she can get me to give her before she gives me mines. Shit. (72)

Booth makes it seems like he has it all planned out. Because he witnessed his parents fail at maintaining a household, he rationalizes his unemployment and that he's going to do the same thing to his kids, "Give [them] 500 bucks then cut out. That's thuh way to do it"(72). Booth 
further concludes that even though they stopped talking to each other, they were very clear about how they would depart from the responsibilities of their life. Booth and Lincoln received $\$ 500$ from their Mom and Dad respectively. This is the only way of life Booth knows. And having time to think about it, he knows that they were in "agreement."

"I didn't mind them leaving cause you was there," Booth says to Lincoln after breaking the news of their parents agreement (74). Booth uses this tender moment to convince Lincoln they should work together. "It was you and me against thuh world, Link," Booth rallies, "It could be like that again" (74). Finally, Lincoln agrees to show Booth how to throw the cards.

Lincoln breaks down each aspect of the 3-Card hustle, "Theres thuh Dealer, thuh Stickman, thuh Sides, thuh Lookout and thuh Mark" (76). Lincoln stages a reenactment where he's the dealer and Booth is the "Sideman. Playing along with the dealer, moving the Mark to lay his money down" (76). Lincoln continues at length the rules behind successfully pulling of the hustle:

There are 2 parts to throwing thuh cards. Both parts are fairly complicated. Thuh moves and thuh grooves, thuh talk and talk, thuh patter and thuh pitter pat, thuh rap and thuh flap: what yr doing with yr mouth and what yr doing with yr hands...The Mark focuses with 2 organs primaritly: his eyes and his ears. Leave one out you lose yr shirt. Captivate both, yr golden... You see what I'm doing? Don't look at my hands, man, look at my eyes..And you standing there thinking how thuh fuck I gonna learn how tuh throw thuh cards if I be looking in his eyes? Look into my eyes and get yr focus. Dont think about learning how tuh throw 
thuh cards. Dont think about nothing. Just look into my eyes. Get yr focus. (79-

Lincoln provides key information about his hustle during these 2 rounds. However, Booth spends so much time trying to guess the right card in the reenactment that he misses the point of Lincoln's lesson. Booth show boats after each successful guess. Lincoln, annoyed with Booth's obnoxious gloating, tells Booth to be the dealer and throw the cards with a "light touch. Like a whisper." Booth will be Booth. Booth ostentatiously throws the cards worse than he did in the opening of the play with "wild and jerky movements."

Lincoln cannot help but laugh at his brother's way of throwing the cards. Lincoln goes on to explain to Booth that he cannot be wild with throwing the cards because people will smell the hustle from a mile away and they will lock him up in prison. He also uses the opportunity to deflate Booth's boosted ego by bringing up the time Booth cost them $\$ 800$ during a hustle:

Thuh hustle was so simple. Remember? I told you that when I put my hand in my left pocket you was to get thuh Mark tuh pick thuh card on that side. You got to thinking something like Links left means my left some dyslexic shit and turned thuh wrong card. There was 800 bucks on the line and you fucked it up. (rest) But it was cool, little bro, cause we made the money back. It worked out cool. (rest) So, yeah, I said a light touch, little bro. (84)

Not only does Lincoln bring up a bad memory for Booth, he demotes Booth by calling him little bro. Throughout the entire reenactment, Booth has been referring to himself as 3-Card. At the height of Booth boasting, Lincoln says, “Ok. 3-Card. Cool. Lets switch. Take thuh cards and show me what you got" (83). Lincoln then oddly attempts to smooth things over with Booth and 
reassures him that it was ok because they got the money back. Booth snaps back to the current situation. He is waiting for Grace and asks Lincoln the time. Booth reacts explosively and storms out of the apartment stating that "I aint nobody chump" (85).

Act 2, Scene 2; Scene 6

\section{Synopsis}

Lincoln enters the apartment high on liquor with cash in hand. He has been hustling on the streets. Lincoln talks to himself. He brags about how he is back and in charge. Booth appears. Booth had been in the apartment the entire time. In the height of Lincoln's hype, Booth slams the door. They both reveal that they have good news. Booth goes first. He tells Lincoln that there was a misunderstanding for his date with Grace and that she asked him to marry her. Booth asks for Lincoln's news. Lincoln says he doesn't have any news. Booth goes on to talk about how Grace wants to move in soon. Lincoln takes the hint and packs his stuff to leave. While packing, Lincoln gives Booth advice regarding Grace. Lincoln starts to leave. Booth indirectly tries to get Lincoln to stay and brings up mom. Lincoln quickly brings up their dad and how close they really were, much to Booth's amazement. Booth tells Lincoln that he will miss him. Booth takes a picture of him in his work outfit for his photo album. Lincoln then offers Booth to get a job and the arcade. Booth lashes back and brings up Lincoln's ex-wife cookie. Booth reveals that he raped Cookie. Lincoln doesn't care. Booth challenges Lincoln to 3-Card hustle. Lincoln tells Booth he does not have money. Booth proves that he has money: his inheritance. He explains how their mom left them and gave him $\$ 500$ wrapped in a nylon stocking as an inheritance. They play. Booth loses. Lincoln brags about beating Booth. Booth tells Lincoln that he doesn't have to open the stocking. Lincoln teases Booth saying that there may not be money in it and that mom 
could have been lying all these years. He later states that Booth thought he was over-confident that's why he ended up played/hustled. Booth explodes and reveals that he just killed Grace. Lincoln offers the money back to him, but it is too late. Booth tells him to open it. Lincoln reluctantly starts to open it and Booth shoots Lincoln in the back of the neck. Booth blames Lincoln for stealing his stuff and that he's going to take it back. Booth realizes what he's done and wails.

\section{Analysis}

The final scene opens with Lincoln celebrating the return of his mojo. Not knowing Booth is in the apartment, Lincoln talks to himself about how "my shit is back. And back better than it was when it left too. Shoot. Who thuh man? Link" (87). Booth does not reveal himself the entire time and when he does, he plays ignorant to Lincoln's soliloquy. He tells Lincoln he has good news. Lincoln admits he has good news as well and tells Booth to go first. Booth explains that he had the date night's date wrong and announces that Grace has asked him to marry him. Booth then asks for Lincoln to tell him his good news, expecting it to be about him returning to 3-Card hustle. Lincoln says, "Nothing." Disappointed, Booth brags about his news and then further reveals that it is accompanied with bad news. Lincoln must move out because Grace wants to live with Booth.

Lincoln, clearly unworried, agrees with Booth that he needs to leave, "No Sweat." Booth, who was bluffing, is offended that Lincoln can just pack up and leave. "K. I'll Spill it," Lincoln teases, "I got another job, so getting my own place aint gonna be so bad...[as a] Security Guard" (91). Booth recognizes that Lincoln is lying and brings up Grace as a way to cope with the devastating news that his brother has started hustling again and plans on leaving him out of 
the picture. Lincoln continues to tease Booth claiming that Grace will not stay with him if he doesn't have any plans for life:

You gonna have to get some kind of work, or are you gonna let Grace support you? She might want you now but she wont want you for long if you dont get some kind of job. Shes a smart chick. And she cares about you. But she aint gonna let you treat her like some pack mule while shes out working her ass off and yr laying up in here scheming and dreaming to cover the fact you dont got no skills. (92)

Booth does not appreciate Lincoln talking negatively on his situation with Grace. Unfortunately, he is stricken with the image of his brother packing up his things and leaving that he reacts appropriately. He, instead, acknowledges his true feelings, “ Im gonna miss you — coming home in that getup. I don't even got a picture of you in it for the album" (94). Lincoln allows Booth to take a picture of him for the album.

After this short lived tender moment, Booth deliberately recalls his sexual encounter with Lincoln's ex wife. He explains that she approached him for sex due to her dissatisfaction with Lincoln impotence and infidelity. "And then, just like that, she changed her mind," Booth confesses, "But she hooked me.” Booth raped Cookie. Slowly, but surely, Booth uses this moment to rile up Lincoln until they argue about the cards. Booth tells Lincoln that he can beat him in the cards. And to make it real, Booth puts down his $\$ 500$ inheritance. Lincoln wins and takes Booth's money.

Lincoln mocks Booth for his poor attempt to learn the cards, his sentimental attachment to his inheritance, and his emotional state. Lincoln tells him that their mother could have lied 
about his inheritance. Booth hadn't opened it since she gave it to him so Lincoln insinuates that she played him like he just did. "Fuck you Fuck you FUCK YOU FUCK YOU," Booth mentally snaps and reveals, “I popped her. Grace” (111-112). He breaks the news that Grace would not take him back because he had nothing going for him. So Booth figured if he could not have her, no one else could either. He then turns his fury on Lincoln:

That Booth shit is over.3-Card thuh man now. Who thuh man now, huh? who thuh man now?! Think you can fuck with me, motherfucker think again motherfucker think again! Think you can take me like Im just some chump some two lefthanded pussy dickbreath chump who you can take and then go laugh at. Aint laughing at me you was just laughing bunch uh bullshit and you know it. (113)

At this point, Lincoln offers him the money but it is too late. Booth tells him to open it. Lincoln sits down to open the inheritance. Before he can open it, Booth shoots him in the back of the head. Booth has lost everything: his parents, his brother, his girl, his mind. Booth repeatedly explains to his brother's corpse that the inheritance was his from the start and that Lincoln blew his inheritance thinking that "he was all that". Booth grabs Lincoln's money roll and proclaims that he is going to " go out there and make a name for [himself] that don't have nothing to do with [Lincoln]. And 3-Cards gonna be in everybodys head and in everybodys mouth like Link was"(114). Booth sees his inheritance in Lincoln hands and goes to grab it. He, finally, realizes what he's done and screams, "AAAAAAAAAAAAAAAAAAAAH"

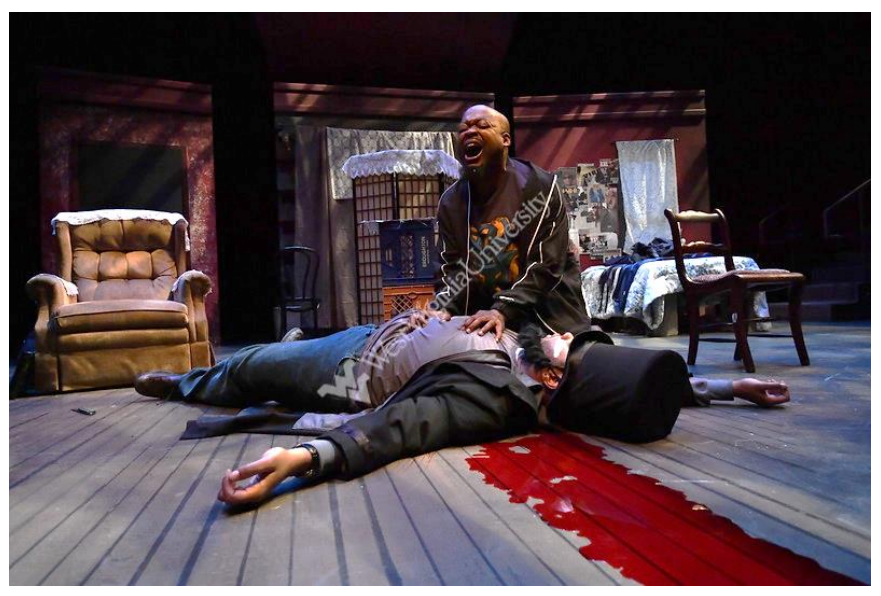




\section{Themes}

\section{Identity: What's a black play?}

As mentioned earlier, Parks is an acclaimed black playwright, known for writing black plays. But what is a black play? Does it alienate non black people? Why bring in a guest director when we have capable directors available at WVU? Within the black community, the idea of a black play often conflicts with each other. For example, August Wilson and Suzan-Lori Parks' views differ considerably. In What is a Black Play? Tales from My Theoretical, Sandra Shannon calls out the two differences by setting up the initial problem with the label "black play:

"Does the black playwright determine a black play?". "Does the focus upon the black experience define a black play?" "Must a black play feature a black cast?" and "Can a playwright of another race or culture write a black play?" fuel complex philosophical debates that do more to raise consciousness than to provide answers...Clearly, the twenty-first century has brought with it a multiplicity of variables that must be considered when trying to come to grips with what exactly determines a black play. From the color blind casting phenomenon to increasing cross cultural influences and the blurring of racial boundaries, the phrase "black play" seems tenuous at best. Also, now more so than ever, a surprising number of playwrights who happen to be African Americans have taken to defamiliarizing, deconstructing, and even outright rejecting traditional.”(Shannon 603)

Suzan-Lori Parks is a playwright that follows this newest trend. She argues "As there is no single 'Black Experience,' there is no way to write or think or feel or dream or interpret or be 
interpreted"(603). Parks uses African Americans as tools in her plays writing "both about and NOT about the 'black experience.' African Americans have a rich diverse yet unknown background. We all come from various parts of Africa and after years of slavery, breeding, and rape, our immediate background and familiar relations vary immensely. African Americans' mindset evolved distinctly over the years. We are like snowflakes; Cliché? Yes. Sadly true? Definitely. We are constantly looking for a way to validate our existence and our identity without conforming to negative stereotypes placed on us by historical and societal pressures. Parks unchains us from this thought by challenging the norm of the black experience. I am black and my experience is my experience.

August Wilson views the definition of black plays differently. Shannon contrasts Parks' perception of black plays by arguing that Wilson wants to keep 'Black' in Black plays. She strengthens her argument by stating Wilson would reject a white director and say, "he is not black. He is not a product of black American Culture--a culture that was honed out of black experience and fired in the kiln of slavery and survival? and he does not share the sensibilities of black Americans"(603). Shannon follows up, "Put simply, black experience+black playwright +black director= a black play. Wilson spent his late teens and early 20s during the Civil Rights Movement. This movement prompted honest representation within theatre to bring awareness to the unique black voice. As a product of the Harlem Renaissance and the Civil Rights Movement, he felt like it was imperative to stick to our "roots" in the arts. He infused culture, history, and language known specifically to the black voice in to his works. The Pittsburgh Cycle, for instance, chronologizes the black experience during the $20^{\text {th }}$ century. With this 10 play cycle, Wilson became a staple for the black voice in theatre and paved the way for black artists. Black actors should be familiar with his plays. We need to understand and remember where we come 
from and what makes us unique. We must not lose our identity. And it starts with knowing the past.

Wilson and Parks should not be pitted against each other. On the contrary, they should be viewed as a piece of a bigger puzzle, like Martin Luther King compared to Malcolm X. They may have different approaches, but they both appreciate the narrative the American history provides. Their vision is clear, but the answer to the initial question is not. Ultimately, a black play is difficult to define and yet easy to identity. A black play in the theatre world compares to that of rap in the music world. Like a black play, Rap's language, sound, rhythm, and voice are different. And like rap, the stigma of being a black play potentially damages its viewership and reliability. This black play 'haven', again, can turn some on while turning off others. It is up to black actors to remain authentic to our voice and not worry about labels or deterring others.

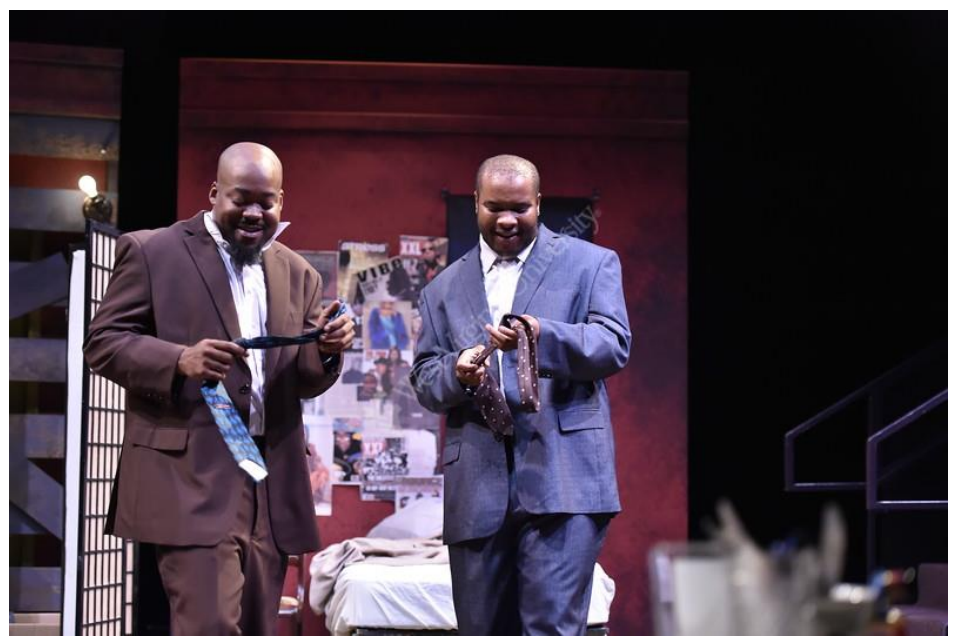




\section{Knowing What is and What Aint}

Topdog/Underdog plays with the notion of illusions. What is reality and what is a façade? According to Michael LeMahieu in The Theater of Hustle and the Hustle of Theater: Play, Player, and played in Suzan-Lori Parks's "Topdog/Underdog, "Parks stages a drama that achieves its effects by prompting the audience to look for something hidden only to distract them from, and then ultimately remind them of, what lies in plain sight"(LeMahieu 35). There are many examples of foreshadowing sprinkled within the play that have made it to my analysis above: The first example being the names Lincoln and Booth. American history teaches us that Booth assassinates Lincoln. Parks' decision to name them makes their fate instantly recognizable. With all the attempts to not forget about the brothers' fate, Lincoln's death does come as a surprise for some. The Realism behind the character's intentions and given circumstances causes readers and audience members to become more invested in the story of the brothers. In terms of a hustle, you may consider them as a mark in this instance.

Another glaring example is the gun's presence in the first scene. According to Brian Delaney's Chekhov's Gun and Nietzsche's Hammer: The Biotechnological Revolution and the Sociology of Knowledge, "A gun placed on the wall during the first act of a play must be used by the third, Anton Chekhov advised young playwrights" (Delaney 167). If a gun appears on stage, it must be fired at some point in the play. Lincoln and Booth's first and last interaction on stage has a gun between them. However, by establishing the gun so early in the play, most forget the gun plays a part in the story. Again, the direct nature of Parks' Realism can be perceived as metaphorical which causes it to be dismissed as Realism. This metaphorical perception weakens the presence and danger of the gun and their fate. 
Illusions are not foreign to the African American culture. Derek Iwamoto's Tupac Shakur: Understanding the Identity Formation of Hyper-Masculinity of a Popular Hip-Hop Artists describes Tupac's image as a façade. He states, "Under his rough and tough image and despite his gangsta lifestyle, Tupac is regarded as a sensitive and progressive person who was more knowledgeable than most people gave him credit. It is my contention that Tupac was and still remains misunderstood by his critics" (Iwamoto 44). Tupac was a critically acclaimed rapper in the 90s. He had a rough exterior that glorified gangsta rap. Tupac was not always like that. Iwamoto continues by explaining that this façade is a "coping mechanism to combat racial oppression, besides a way of validating one's manhood. There were times in Tupac's adolescence when he was teased by his peers due to his 'pretty-boy' and 'artsy' image. This bothered him so much that he began to take on a more tough and manly attitude" (Iwamoto 45). Tupac created a different reality, an illusion, to get through his life.

In Topdog/Underdog, Booth typically lives in the world of illusions. Everything he does is a show while he maintains a boisterous demeanor. Booth ritualistically brags/lies about his endeavors with Grace. Booth creates lavish displays of window dressing, ie stolen clothes neatly spread across the apartment and his romantic setup for his date with Grace. Booth commits to keeping up the illusion that "Grace asked [him] to marry her," while in fact "[he] popped her. Dead." Booth's dedication to his reality, which is indeed an illusion, allows him to survive his destitute circumstances. Lincoln, however, never seems to be bothered by his braggart of a brother. Maybe Lincoln sees the truth behind Booth's false front. Whatever the case may be, Lincoln recognizes that Booth has a warped sense of reality which would explain why he continuously feels like Booth is not ready to hustle on the streets. Lincoln's intuition rings true 
when he witnesses the way Booth throws the cards. Booth's idea of throwing the cards is like his views of reality: Fake it till you make it.

On the other hand, Lincoln understands reality more than Booth. This allows him the ability to manipulate reality even more, thus causing him to have a stronger illusion. A prime example would be the final scene when Lincoln hustles Booth out of his money. Booth complains about how the game doesn't initially feel real. Booth suggests putting money down. Lincoln does not want him to do it. Booth is persistent to play the game. Lincoln caves. As we know, Lincoln wins the money. He gives Booth one more lesson:

Ooooh you certainly was persistent. But you was in such a hurry to learn thuh last move that you didnt bother learning the first one. That was yr mistake. Cause its thuh first move that separates thuh Player from thuh Played. And thuh first move is to know that there aint no winning. Taadaaa! It may look like you got a chance but the only time you pick right is when thuh man lets you. And when its thuh real deal, when it's thuh real fucking deal, bro, and thuh moneys on thuh line, that's when thuh man wont want you picking right. He will want you picking wrong so he will make you pick wrong. Wrong wrong wrong. Ooooh, you thought you was finally happening, didnt you? You thought yr ship had come in or some shit, huh? Thought you was uh Player. But I played you, Bro. (111)

Lincoln followed his hustle strategy to a T. It is important to recognize that the hustle started in Scene 5, not the final Scene 6. One could even argue it started long before the play started. Lincoln said that the dealer has to act like they do not want to play in order to keep the mark intrigued in the game and willing to bet their life. Lincoln prevents playing against his brother 
until the final moments of the play. Booth was certain that he was going to win. However, Lincoln snaps Booth back to reality.

Booth's realization of the reality that surrounds him causes his mental breakdown. Even though his inheritance from his mother was important to him, it wasn't until his illusion shattered and he was forced to deal with his reality that he completely lost it. Booth's reality now consists of him being a suspect in two murders with no personal connection with anyone. He killed everyone important to him. He is alone; a reality Booth is not ready to face. 


\section{Who the man?}

Topdog/Underdog questions African American masculinity by equating being a “Topdog" as being "thuh man". Suzan Lori-Parks capitalizes on the historical views on success through the lens of African Americans. The play seamlessly ties masculinity to financial success. Within the American Dream, the responsibility of the man of the house is to provide for his family. Money is usually the key in effectively achieving this goal. In Scene 2, Lincoln enters the apartment saying, "Poppa done brung home thuh bacon" (30). Booth assumes the role as Ma to complete the minstrel ritual. Money declares Lincoln as the Man in this equation, where Booth, the homeowner, serves as the woman. These established roles slowly create a shift in the scene. Booth takes the money, budgets it out, lectures him on getting a woman, and then gives him back his share. He came in with $\$ 314$ and ends up with \$9. Lincoln's short lived celebration succumbs to the news of possibly losing his job, with benefits, and being left with a meager amount of money.

Masculinity also ties to aggressive sexual prowess. Topdog/Underdog boldly qualifies what makes a man. Iwamoto declares, "a real man should be tough, aggressive, daring, and have physical strength" (45). Iwamoto goes on to say that "given that the media provides minorities only minimal and stereotypical representation of males, many minority youth exaggerate these hyper-masculine characteristics in their public personae, in order to prove themselves and be respected by their peers" (45). Topdog/Underdog places Lincoln and Booth in the 90s. Gangsta Rap reigned supreme during this time period and this music shaped their idea of masculinity. "Anybody not calling me 3-card gets a bullet," Booth says to assert his dominance and to enforce the rule that he changed his name (24). "I'd yank off the beard throw it on the ground and stomp it, then go strangle the fucking boss. Thatd be good. My hands around his neck and his bug eyes 
bugging out," Lincoln says to himself if he had the opportunity to assert his dominance over his boss (59). To them, this violence denotes what being a man really is.

Violence/aggressive behavior is not the only thing that discerns masculinity. Iwamoto proclaims, "Men are also encouraged to have an "emphasis on sexual prowess, sexual conquest, and sexual aggression" (45). Apparently, a man should have aggressive sex, often, with multiple women. One example that sexual prowess defines masculinity in Topdog/Underdog is in Scene 3. Parks attempts to simulate guy talk between brothers:

\section{Lincoln:}

Tell Link thuh stink. (rest) Howd ya do her?

Booth:

DogStyle.

Lincoln:

Amazing Grace

Booth:

In front of a mirror

Lincoln:

So you could see her. Her face her breasts her back her ass. Graces got a great ass. (46)

This banter, based on the play, declares them as men; vulgarly speaking of their sexual conquest. If you want to be considered a man, you must think the same way as they do. The play questions this notion by having two brothers talk about sex in an intimate setting. They seem to bond over being men that casually talk about sex, discussing condoms brands and sexual positions. However, when each other's manhood becomes tested, they try to undermine each other. In the same scene, Lincoln says Booth has "Blue balls" and Booth responds by saying Lincoln has a "Limp Dick." Both insults insinuate that one has not had sex; both are not by choice. If both are 
not having sex and both do not have any money, ultimately who is the man, based on the culturally and societally understood definition of a man?

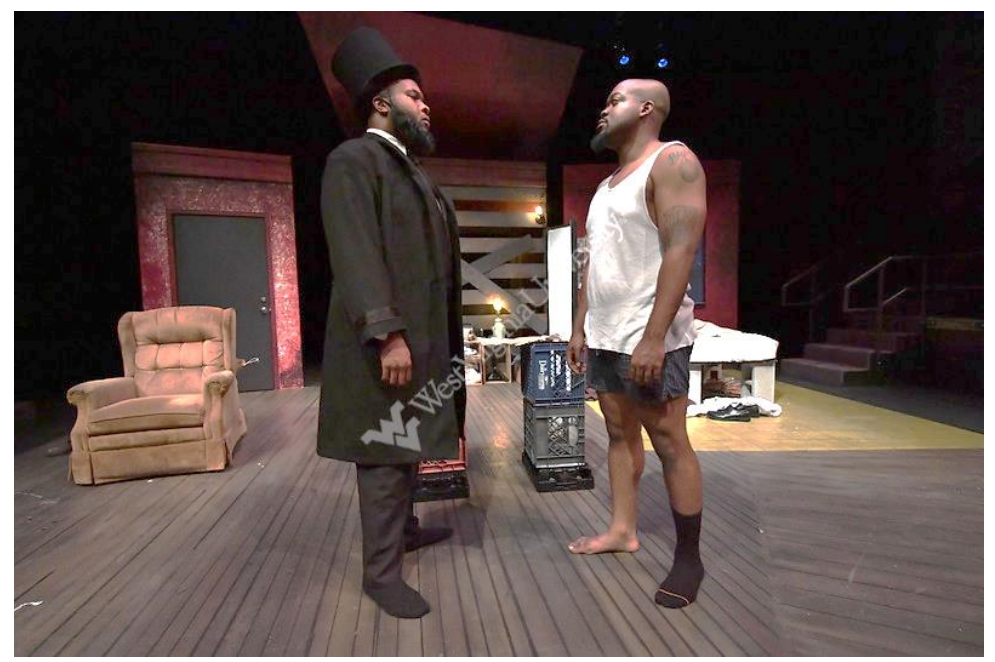




\section{Finding Booth Within Myself: \\ Uta Hagen's Methodology}

Who am I?

I am a 29 year old African American Male living in New York. I am a younger brother to Lincoln and boyfriend to Grace. My birth name is Booth, but you can call me 3 Card. And I mean that. I practice 3-card monte religiously. I like to dress sharp. Oh, and I boost (steal) anything that I want. Anything. From clothes, to med-sin (Alcohol), to "Fuck books," to even a partition that separates my bed from Lincoln's, um, "space”.

\section{What time is it?}

We are at the tail end of fall moving into winter. It's pretty cold outside, but not completely unbearable. We must wear, at the very least, a jacket if we decide to go somewhere. I tend to wear bigger coats. They serve two purposes: Keeping me warm and stealing.

\section{Where am I?}

I am in New York. This busy city is full of hustlers and the soon-to-be hustled. Everybody is trying to make their way in this city and that includes me. I love this fast life and what it's made out of me.

\section{What surrounds me?}

Failure surrounds me. My apartment is decrepit. My bed sits on cinder blocks. My radiator is broke. I have no running water. I have no bathroom. My depressing brother lives with me. But I will not let that get me down. I still have $\$ 500$ and a dream.

\section{What are the given circumstances?}

My parents left Lincoln and me when we were 16 and 11 respectively. My mom left, then 2 years went by and my dad left as well. They both gave me and Lincoln $\$ 500$ respectively before 
they abandoned us. It's been my brother and I since I was 11 years old. Since he was 16 , he became the man of the house and we both took odd jobs to survive. We even had to learn how to keep that child protection bitch from stopping our flow.

\section{What is my relationship?}

I have a close relationship with my brother. It's been us against the world for years. I feel, however, he keeps me away from the things that make me happy. I still love him though. I know he's going through a lot of things right now so I understand why he feels so sullen all the time. But if you wallow in your self-pity too much you'll succumb to it. That's why I decided to push. Push to make my dream come true. Push to make plans for both. Push to cheer my brother the hell up.

I've dating this Grace for a couple of years now. We broke up because ...well she said we broke up because I don't have any ambition. Whatever that means, I have ambition. I will prove it to her that I can be that man that she wants. I know she'll take me back if I put more of an effort.

\section{What do I want?}

It is simple. I want money. I need money. If I had money, I wouldn't have to be in this bum apartment anymore, I could get Grace back with me, and even my brother would be at a happier

place. If we could make this money together, our bond would strengthen and we would own these Streets. Yea, 3-Card Booth

What's in my way?

Link is standing in my way. Hands Down. He still treats me like I am some young boy who can't take care of himself. I mean, come on, he's living with me. He used to be the king at 3 card monte. He had everything that I could dream of. I idolize him. He just doesn't get it. Every time I 
try to talk about this game, he says I'm not ready and that I need to practice. He then makes me out to be insensitive to his friend Lonny dying. Apparently, he hasn't been the same since Lonny died. I wish I could make him realize that he still got me.

What do I do to get what I want?

I am the housekeeper. Link brings money to the house and I maintain the house. So it is up to me to keep lighthearted for my brother. Now, I know there are times when I get upset. I know I can be convincing and that my upbeat energy is contagious so it infuriates me that he doesn't give me a time a day when I am trying to be encouraging and optimistic through his situation. However, sometimes I got to become insulting and/or threatening to get what I want. Like kick him out. But to be honest, I like him living with me. I'm merely bluffing. 


\section{Rehearsal}

\section{First week}

After a summer of anticipation, Topdog/Underdog's rehearsal finally approached. It's important to note a few things that led to the first rehearsal. My peer/co-actor, Lonnie DeVaughn Simmons, and I auditioned via skype for an Atlanta based director by the name of Cleo House. After he cast the show, we spent time speaking with him about his vision and things he would prefer us to do prior to the first rehearse. He expressed the concept that Lincoln and Booth's lives were shattered from past experiences and that his stylistic approach would mirror their painful past. Our world would be a shattered and fragmented apartment. To our surprise, he seemed very open with his concept especially since he's always wanted to direct it. I've had directors in the past that were not as open with their overall vision or concept. We exchanged contact information and he gave us homework: Research images for inspiration, communicate through email any concerns that we may have for him and plan to be off book before the first rehearsal. All seemed well, until our director dropped out unbeknownst to us. Luckily, after months of silence from the school, we learned that another director had taken the job. The name provided: Jade King Carroll. I researched her and learned that she had tons of experience with directing August Wilson. She was also a was awarded The Paul Green Award for Outstanding Emerging Theatre Professional from the National Treasure Conference and The Estate of August Wilson. Her credit proved that she was more than capable of directing this show.

On the first day of school, rehearsals were set for 6:30p.m. Exciting!!! However, our director had not arrived at the school yet. It became Lonnie's and my responsibility to drive 90 minutes to Pittsburgh to pick Jade up from the airport. After what seemed like a comedy of errors, we made our trek to Pittsburgh, late, in a hot, school sponsored, van to pick up our 
director. Now, I don't say all these things to use this as a platform to vent my frustration, however I think it is vital in setting up my first day of rehearsal. It's actually pretty funny every time I think about it. Three irritable adults riding in WVU's Puppet Mobile with the windows down while children waved at us on the highway. We recognized our circumstantial humor and ended up bonding over it. In fact, Jade used this opportunity to start detailed introductions: Where are you from? Why did you get into theatre? How did we get in to this school? We got to know each other pretty well. We then became eager to return to Morgantown and ready to work. Ultimately, our actor/director relationship began without a hitch. I couldn't ask for a better way to start rehearsals: With a good laugh and a provocative discussion.

We spent the first week of rehearsal doing table work. We discussed all the aspects mentioned above in my text analysis. I must say, I enjoyed the way we broke down the script. We did our initial read through. Then we read each scene separately, discussed learned information, and questioned intentions for both characters. We concluded our talks (or sometimes debates) by rereading the respective scene. This took the whole week to finish, because our conversations were so detailed. During our final readthrough, Lonnie and I decided to use our Meisner training.

We sat in two chairs across from each other and read the play. Due to our Meisner, which I will go more into detail later, we allowed ourselves to take everything "personally." This vulnerability forces us to rely on our human instincts to remain connected to each other and to carry our emotions. Lonnie and I previously found Meisner effective in the past due behavioral foundation; we've became adept at reading behavior. Our ability to read behavior impulses during this exercise fed our "Inner Life." This exercise worked wonders. I felt a strong emotional connection to Booth during the exercise. When Booth kills Lincoln, I realized that I 
had a fury of unexplainable emotions. I needed to take a time out from rehearsals. When we came back, Jade said that she wanted to start blocking as soon as possible and that we should prepare for the upcoming week. She also gave us our off book date, which was in two weeks. I left my first week of rehearsal feeling like I would love connecting to Booth. 


\section{Second week}

"Know the quality of how your body moves within the space." Cathy O'Dell

We dissected the play. Now, it was time to put it on its feet and block the movements.

Before starting a show, I like to look at negative aspects of past productions to prepare myself for possible challenges that I may encounter. One possible and notable down fall that I discovered is that the blocking can seem a tad bit "considered and choreographed" (Brantley). This play seems seemingly easy to produce since the play only requires two actors, a set that doesn't change, and somewhat contemporary clothes. I believe the trap rests in the props and costumes. Parks uses lengthy descriptive, sometime non-negotiable, stage directions. It appears that Parks' attempt to keep the audience engaged with just two actors emerge in the play's "busy work." The many props and on-stage costume changes establish rituals and routines that both brothers share within this limited space. It would be tempting to choreograph every tiny detail which can cause the play to lose is authenticity. Jade thought differently.

Jade wanted to stay true to the text. If the stage direction told us to do it, we did it. Lonnie and I tried to read the stage directions while we executed them. It did not work. We needed the assistance of the stage manager(SM). It was like the game "Simon Says". The SM would call out an action that we would have to do and we complied. The most challenging blocking moment was the beginning of scene 2. Parks sets up scene 2 with this description:

Friday evening. The very next day. Booth comes in looking like he is bundled up against the cold. He makes sure his brother isn't home, then stands in the middle of the room. From his big coat sleeves he pulls out one new shoe then another, from another sleeve come two more shoes. He then slithers out a belt from each sleeve. He removes his coat. Underneath he wears a very nice new suit. He 
removes the jacket and pants revealing another new suit underneath. The suits still have the price tags on them. He takes two neckties and a bottle of whiskey from his pockets and two folded shirts from the back of his pants. He pulls a magazine from the front of his pants. Hes clearly had a busy day of shoplifting. He lays one suit out on Lincolns easy chair. The other he lays out on his own bed. He goes out into the hall returning with a folding screen which he sets up between the bed and the recliner creating 2 separate spaces. He sets up the whiskey and two glasses on the stacked milk crates. He hears footsteps and sits down in the small chair reading the magazine. Lincoln, dressed in street clothes, comes in.

I had multiple marks to hit. Unfortunately, I did not have any costume pieces to help practice unloading a stuffed jacket. I simply mimed the action over and over. It took about thirty minutes and at least 5 run-throughs before I remembered the chain of events. I didn't get comfortable with it until Tech Week when the costumes became available.

After honoring Parks' stage directions, we worked towards blocking the rest of the show. Our set was in a $3 / 4$ thrust. I've acted in this space before with the same configuration. I even had the opportunity to perform in the round on the same stage. Needless to say, I was very comfortable in this space as Booth-- and I needed to be. The setting is my apartment. Lincoln lives with me. The only space that Lincoln can call his own is his chair. The majority of the time, Lincoln would sit in the chair. This meant that I would have to keep the energy up with my blocking. I would say that my movements mimicked a moth to a lamp. I tended to continuously flutter around Lincoln's chair. We carefully went through the play organically creating blocking. 
Every week brought a new personal challenge. For every role, I use my prior training with Uta's Hagen methodology and answer her questions. (As seen above in Research section) I then move on to my characters movements. Michael Chekhov's technique of movement allows me to find a character's physicality within my body. I received training for this technique at my alma mater, University of West Georgia. I was lucky enough to receive additional training here. As a more mature actor, I deepened my understanding of this approach. Cathy O'Dell, my teacher, reinforced that Chekhov created a range of movements that could be applied to our work through psychological gestures (PGs). These gestures, like piercing, pushing, pulling, etc, apply respective qualities to any given line of text. More importantly, these PGs manipulate the overall physical life of the character which gives me the opportunity to figure out how my character moves within a given space.

In search of a rich internal life, it became imperative that I utilize my teaching from Cathy O'Dell to find Booth's Body. She advocated that one has to play around with most, if not all, PGs to find what feels right within our body. Our bodies never lie; we should trust them. I love using movement. My body reacts viscerally to the PGs. For example, when Lincoln claims that Booth doesn’t have money he responds, "I got money!.” With the exclamation present, this indicates a level of emotional connection to the line. I thought about the situation; Booth is overwhelmed with Lincoln's insults. He must defend and protect his manhood. After trial and error, this led me to think the PG, push, works best. I imagined all of Lincoln's insults, the stress of poverty, and the regret of killing Grace surrounding me. I needed to "push" all this negativity away from me and stand my ground. My connection to the situation was strengthened through this search for the perfect PG. 
Again, I typically use Chekhov for all my roles because it helps me form a solid center within my body while also giving me qualities to experiment and discover different nuances that are not readily available. Using the first monologue as a base, I realized that Booth aka 3-Card is high energy and likes to show boat as he practices throwing the cards.

Watch me close Watch me close now. 3-Cards-throws-thuh-cards-lighting-fast. 3-Cardthats-me-and-ima-last. Watch-me-throw-cause-here-I-go. One-good-pickll-get you-in, 2good-picks-and-you-gone-win. See-thuh-red-card-see-thuh-red-card-who-see-thuh-redcard? (rest)You wanna bet? 500 dollars? Shoot. You musta been watching 3-card real close. Ok. Lay the cash in my hand cause 3 cards thuh man. Thank you, mister. This card you say? (rest) Wrong! Sucker! Fool! Asshole! Bastard! I bet yr daddy heard how stupid you was and drank himself to death just cause he didn't wanna have nothing to do witchu! I bet yr mama seen you when you was born and she wished she was dead, sucker! Ha Ha Ha! And 3-Card, once again, wins all the money!!(12)

It was clear that he has confidence and walks as he does. He likes to take up space. As a complete opposite to Lincoln, who just sits in his chair, I pictured Booth like a moth that flutters closes to and around light. This case being that Lincoln is the light. He struts through his own domain. He is the king of his castle. Naturally, I adopted Chekhov's model for glide and float to create physically a character that has swagger. He may have confidence, but he doesn't have the power, hence why he doesn't make space for himself like molding or pushing. Funnily enough, Booth's body came very naturally for me. I left this week feeling accomplished because we finished blocking the show and I found Booth's body within mine. 


\section{Third Week}

\section{"Connect the breath with the thought" Laura Hitt}

This week lines were due. This has been one of the biggest challenges throughout this entire process. Jade was a stickler with the text. She wanted us to honor the playwrights' words. She didn't want us to replace anything from the text. Lonnie and I had a massive task to learn all the lines perfectly. There were few times I would get hung up on getting the text right

:Whata you know of heat? You aint hung out with those guys for 6-7 years. You swore off em. Threw yr heat in thuh river and you "Dont touch thuh cards." I know more about heat than you know of heat. (52)

I constantly got this line wrong. I would say, "You swore them off. Threw your heat into the river and now you 'Don't touch the cards no more." Jade was so determined to make sure that we got each word right that she requested an assistant stage manager to stay on-book specifically for line notes. We received pages of line notes up until opening. I don't think we ever got it perfectly right textually, but we still strived, until closing, for perfect line delivery.

Since line memorization was the goal for the week, I figured it would be a great time to focus on my vocal qualities. One of my biggest reasons for coming to graduate school was to become a better actor vocally. Ever since I've started acting, I'm usually the odd man out for poor articulation and pronunciation of words due to my southern accent. So part of my training here required mastery of my voice and vocal quality. Using Linklater as a roadmap, IPA as a car , and General American as a destination, my professor, Laura Hitt, instilled in us that we must understand the foundation before we can even think about improving our vocal quality. It seemed only right to put this in practice for Topdog/Underdog. And believe me this play was not easy vocally. 
Laura Hitt's training started almost day one for me. As stated earlier, we must understand our vocal foundation. We needed to learn what makes a voice. We started with simple breathing exercises to remind us that breath lays the framework vocally. One would believe that they know how to breathe because they have been doing it all of their life. However, she took that time to inform us of what anatomically creates a voice: Breath. This included but was not limited to, knowing what happens internally within our bodies when we inhale and exhale, how much of potential air capacity we could achieve, what happens to our vocal cords, how it resonates through our body to create sound, and what various articulators we have. Starting from the ground up, we advanced, within a couple of years, to learning how to manipulate sounds to achieve the desired voice; Laura introduced The International Phonetic Alphabet (IPA) as part of our vocal work. In short, IPA is a universal guide that breaks down the various qualities of speech. Learning and mastering IPA tests our understanding of this manipulation allowing us to have the ability to learn any accent.

Topdog/Underdog, again, takes place in New York. Although my training made me more than capable, Jade didn't want us to learn a New York Accent, but rather to be specific enough between each other as actors to create the sound of our world. This proved challenging because I am from Georgia and he is from Maryland. There were times where Lonnie and I would have discussions at length about the pronunciation of shared words. We used terminology from our training in IPA to articulate what sounds to set for our world. For example, the word "Card" prompt a debate on how hard to hit the r. Card was probably the most used world in the play so we needed to come to a consensus. We decided a slight $r$ coloration with a more rounded sound for the a and a light tap for the d. Ultimately, Cards would be [Kaidz] instead of [kard]. Other examples include foø instead of [for](four) and 'twenit instead 'twenti (twenty). In general, I 
wanted us to maintain a hard r-coloration as well as shorten some of the words to make it easier to say at a quicker pace. Lonnie, however, felt like we would have to make some compromise because he believed the words would be hard to understand if we drop the endings of words. In the end, I lost that battle mainly for practical reasons.

This brings me to our ultimate vocal challenge: Rhythm. Overall, the play was fast. The tempo, prescribed by the playwright and enforced by the director, remained upbeat, fast, and steady. The goal was to keep the lines energized by maintaining that rhythm so that when it breaks it had a bigger impact. This rapid fire in lines felt like our syllables were precious in terms of knowing how much emphasis we needed to apply to each syllable. As stated previously, softening the r-coloration was needed. It played right into breath control; more breath releases with hard r-coloration. One example of Booth's fast tempo speech pattern shows up when he tries to convince Lincoln to throw the cards again:

Oh, come on, man, we could make money you and me. Throwing down the cards. 3-card and Link: Look out! We could clean up you and me. You would throw the cards and I'd be yr stickman. The one in the crowd who looks like just an innocent passerby, who looks like just another player, like just another customer, but who gots intimate connections with you, the Dealer, the one throwing the cards, the main man. I'd be the one who brings in the crowd, I'd be the one who makes them want to put they money down, you do yr moves and I do mines. You turn yr head and I turn the card-... We could be a team, man Rake in the money. Sure there'd be some cats out there with fast eyes, some brothers and sisters who would watch real close and pick the right card, and so there'd be some days when 
we would lose money, but most of the days we would come out on top! Pockets

Bulging, plenty of cash! And the ladies would be thrilling! (24)

Booth is the king of run-on sentences. It made it hard at times to understand the flow of the language. I needed to know the thought behind these sentences in order to have adequate breath control. "Keep the rhythm up and make decisions faster," Jade reiterated throughout the process. Jade didn't want us to stop the rhythmic train. She constantly advocated that we needed to find the rhythm and yet "do not rush." She told us to think the thoughts faster so that we would not stumble over the speed. It was easy to rush over the thoughts in order to get the words out. I even felt out of control with the language if I tried to mimic previous rhythms experienced during rehearsal. I learned that I must always stay active with the breath so that I didn't get complacent with the line delivery. And since I would be shaky on lines until tech week, I figured I had ample amount of time before opening night to figure out what Jade needs from me. 


\section{Fourth Week}

"Acting is living truthfully under imaginary circumstances" Jerry McGonigle via Meisner

At this point of the rehearsal process, I needed to dig deeper to connect more with

Booth. I remembered another issue that sparked criticism during the original production.

Booth's emotional bipolar nature required an actor that pushes for those highs and lows. Ben Brantley of the Ny Times commented on the difference in Cheadle's performance as Booth and Mos Def's performance:

Mr. Cheadle was a spirited Booth, but he was never scary in the way the character has to be if the play's second act is going to work. Mos Def, best known as a rap artist, finds both the delightful innocence and the harrowing brutality in the role of a little brother who never grew up. (Brantley)

On paper, Booth reads as the upbeat younger brother of Lincoln. When he moves, he moves with a purpose and has the energy to sustain it. As he transitions from the Topdog to the Underdog, we see that when he is pushed in a corner, he has a dark side. So dark, he kills the love of his life and then, in a fit of rage, shoots his brother. Logically, we would assume that it would take a complete shift in tone for a younger brother, who admires and loves his older brother more than anything, to kill said brother knowing that he is the only family he has left. Without the ability to, again, reach for the highs and lows of Booth, the last moment loses its power and the tragedy becomes lost.

I did not want to fall into this trap. However, I was apprehensive about my capability to deliver what the text required; allowing myself to be angry enough to kill out of rage then later regret killing my brother. I remember what Sanford Meisner said in, Sanford Meisner on Acting: 
[This is] difficult to do because we've been trained since we were children to be restrained emotionally — at least some of us have — and every day we're constantly aware of what our proper limitations are. We always know what our boundaries are and it's difficult to break them, even in an acting class. Emotional freedom gets easier when you try to go along the path your inner life is sending you. (Meisner 103)

This passage resonated with me. As I discussed earlier, men are rigid and strong. They do not allow themselves to get emotional. That's considered a feminine way of handling things. The media portrays African American(AA) men as violent deviants with a hardcore appetite for sex. I will be completely honest. Growing up as a sensitive AA willing to show emotion, I experienced positive punishment operant conditioning, where I would get in trouble because I would get emotional. It was a way to force me to "Man-up." I've gotten to the point where I can recognize how I feel about something and numb or tune it out so that it does not affect my day.

My emotional blockage did not serve me justice. Prior to WVU, I resorted to comedy in stressful situation, including dramatic scenes. I could always tell that the stakes were not high enough, but people laughed and I thought it was the way to go. Luckily, I was able to confront my emotional baggage with Meisner. As he stated, I realized my limitations and knew they were going to be hard to break. According to him, I should strive for emotional freedom. This a better way to work on my inner self. But what is my inner life, in terms of connecting with Booth?

It hit me that the cause of the problem is also the solution in this situation. The main reason I complied with blocking my emotions is to seem manlier. However, I would internally feel "feelings" and had no way to let them out. I started to question my masculinity for not being 
able to discard my emotions and be the stoic manly man that society wants me to be. My connection to Booth is NOT FEELING LIKE I AM GOOD ENOUGH. This thought fueled my inner life:

Booth always wants approval from his older brother. He wants to be Thuh man. He wants to live like Lincoln did in the past while he was hustling. He wants to know if he is good enough for Grace. He wants to know that he can do things that his brother is capable of doing. He wants to know why he's not good enough to hustle cards. Why he's not good enough to hang out with his father. Why he's not good enough to keep his Mother by his side. Grace by his side. His brother by side. Alone. Always alone. I am used to it. Mom Leaves. Dad Leaves. Lincoln leaves me to hustle with his friend Lonny. I'm too young. Alone all day. At home. Alone. Why am I not good enough to keep people in my life? (Journal Entry)

This play hits pretty close to home. I do not necessarily feel comfortable revealing some of my inner life, but I believe it is essential in marking my journey as an actor. I noticed that I started talking about Booth in third person and that it gradually turned to first person. I realized I related to Booth much more than I thought. I battled my inner demons, just as Booth is battling his loneliness. When I first read this play, I did not realize how much he was suffering. This process made me dig deep emotionally and the more I portrayed Booth in rehearsals, the more I comprehended and appreciated the complexity of Booth. Like Booth, life is filled with complexities. I mentioned earlier the themes I noticed in the text: Blackness, Manliness, and Illusory. Am I Black enough? Am I Man enough? Is this a reality I want to face? Am I the only one that feels this way? These themes and questions add to life's complexity on a daily basis for me. Again, I 
apologize, but I am not willing to talk much more in detail about it all, but I will say that loneliness can drive you crazy.

The acting portion of our training resides in the Meisner technique. Our goal as actors is to connect with text as best as possible. Meisner forces you out of your head so you can react in the here and now. Booth's feeling of inadequacy and loneliness was enough for me to set fire to my inner life. All I had to remember now during rehearsals is the foundation laid by Meisner via Jerry McGonigle: "What is happening to you now? How does that make you feel? Act accordingly. Listen and repeat." The rest seemed to come out almost effortlessly. Granted, I needed time at the end of a run to gather my thoughts and let go of my emotional stage. 


\section{Fifth Week}

Yay! Tech week is here. This is that time where you realized you blink and the process is almost over. Time flies when you are having fun I guess. Even though I was tired because we'd been rehearsing non-stop to make up for me being sick during week 4 , I was excited to see the technical aspect come to life. I came to rehearsal and saw the set. It matched the rendering completely. The apartment looked decrepit with blood color walls. Our set designer, Imani Johnson paid close attention to details, especially when it came to my section of the apartment:
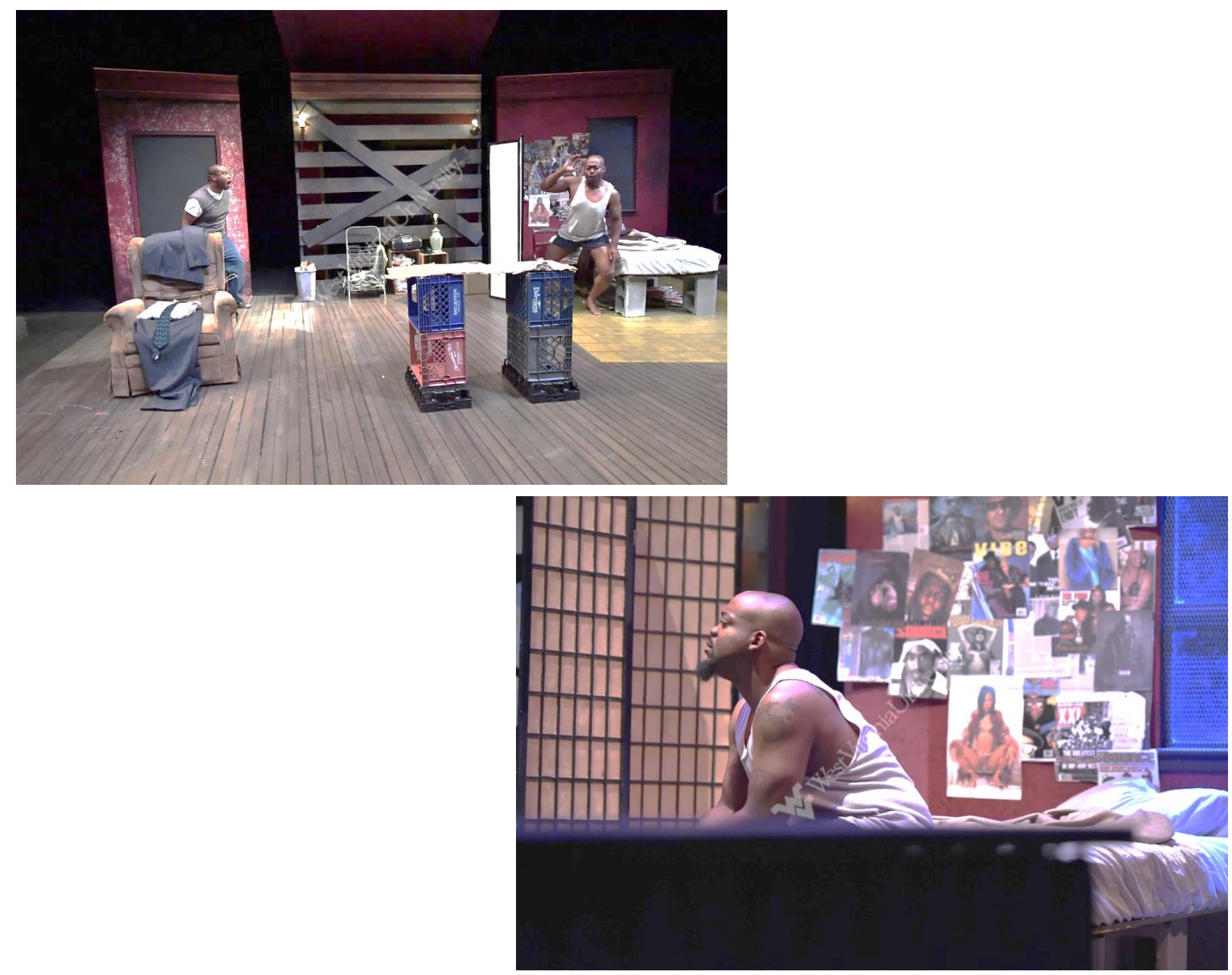
Tech week has a way of hindering the momentum of a show. We had a few complications. For starters, Lonnie and I had a few quick changes on set. We didn't get any of the costume pieces until first dress, which is the last few days of tech. They also had to teach me how to open a bottle of champagne. I do not like sudden loud noises so I was nervous about opening the bottle. Jade is a former bartender. She taught me the safe way of opening it. After all the technical kinks had been worked out, we were able to get a few runs in with costume. 


\section{Performance}

\section{General Assessment of the Run}

I'll admit that I became nervous as the show approached its opening. And it wasn't normal opening night jitters. Based on the language alone, I assumed this play would be off putting to the West Virginian audience, especially being in a red state with Trump as president. (Not going political, just stating facts). I figured there would be some type of backlash or poor reception with the recent reports of harassment on campus. Nevertheless, a show must go on.

During the first run of the show, audience members seemed eager to be there; my opening monologue met laughter from tickled patrons. I sensed the audience was engaged in the story throughout the run. After the two hour show ended, Lonnie and I gradually stood up from our emotional state. Silence filled the air. Then an eruption of applause rushed our way. It was like that the entire run. It was as though the audience did not know how to perceive the ending of the play, but realized the dramatic nature of the moment. I guess they couldn't help but applaud. I felt as though Lonnie and I did the show justice. I was proud.

There were a few notable mishaps during the run of the show. When Lincoln finally told me that he will teach me the cards, I frantically got rid of the romantic setup intended for Grace. In the midst of the excitement, I dropped the entire bucket of ice, spilled the wine, and I slipped on ice. Lincoln/Lonnie said, “ Oh, Shit.” The audience loved it. Another mishap was not knowing the placement of the cards. Jade, Lonnie, and I strategically placed the cards in a certain order that guaranteed that I lose at the end of the play. With this placement, one card looked differently from the others. This allowed me to guess correctly and incorrectly depending of the circumstance in the play. Unfortunately, in one run of the show, the cards were not set 
properly. When Lincoln shuffled the cards, I did not know which one was the winner. I needed to select the winner to progress the story. In a split second, Lonnie looked at me right before I selected the card like, "Please choose the right card." I selected a card; It was the right one! I genuinely jumped for joy and he sighed out of relief. We had some other mishaps that were just funny to deal with: A soda exploded in Lonnie's face, someone forgot our chair so I had to eat on the floor, my gun got stuck in my jeans when it was time to kill Lincoln. These occurrences never fazed our well-rehearsed production. 


\section{Evaluation}

\section{Review of the run}

Overall, the run and audience feedback was positive. Who would have known that this would become a hit! I suspected that there would be a language barrier for my students. I thought the style would turn them off. Luckily, the comedy and the story reigned supreme and captivated them from start to finish.

I've been teaching here for about two years. I require my students to watch every play and write a response paper about the productions. My students do not shy away from being brutally honest. There have been shows that students just did not like in the past. The good news is that they loved Topdog/Underdog. They thought it was funny, entertaining, and sad. Quite a few people even teared up at the end.

I don't compare my students' positive opinions of Topdog/Underdog to the negative views from shows. I refuse to diminish the hard work from the other shows. However, I said this to make a point. My students' wick for the appreciation of theatre typically remains short, including some of the scenes they chose to perform. Their ignorance makes them more cynical toward the elements involved with making a production. Nevertheless, this proves the significance of executing a story the right way while also connecting with the audience.

I feel that this run went swimmingly. There were a few mishaps like a missing chair on stage, my gun getting jammed, sodas exploding. Each mishap was handled professionally. They didn't distract from the story. This is one of the few shows in which I would not change anything. Even if I were to revisit this show, I still wouldn't change anything. No, that's a lie. I 
would possiblly change the venue. I would prefer everything to be the same but maybe produced in a different city or market. But hey, that's just wishful thinking. 


\section{Conclusion}

\section{Learning Outcomes}

My connection with Booth was strong, possibly too strong. I learned from this experience that I must protect myself mentally. Using Meisner during this process, although very helpful, consumed me with residual emotions. Two hours of reading each other's behavior which builds to a climatic ending with me shooting Lincoln and weeping over his corpse left me in a vulnerable state. Most characters I play have been either villainous or happy go lucky and sometimes both; I was not accustomed to this. I found myself in a "mood" throughout the day. My sullen mood was received negatively. I experienced instances in class where my professor would call me out for my standoffish temperament. This was clearly not my intention.

I eventually noticed how emotionally and mentally taxing this role was. In order to survive the rest of graduate school, I needed a remedy. I figured the best way to snap out of this rut: Laughter. I found that telling jokes with Lonnie right after the show to cool the atmosphere allowed me to release all the negative toxins left over from a run. Now this doesn't mean that I tried to completely forget about what transpired. It simple means that I needed to compartmentalize my mental state, save it for the stage, and release when the time was right. With that being said, my mastery of this skill personally became noticeable towards the end of the run. It made me regret not learning this lesson sooner.

Another thing I learned, or rather that enforced what I learned, was that universal themes and a good story can manipulate any audience. As mentioned before, I was concerned with how this audience would perceive this play. This is a black play. I was certain that West Virginia had never produced anything like this. Our student based audience had not been accustomed to edgy and thought-provoking plays on this scale. Yes, we produced "Race" by David Mamet a year 
earlier but it served more like a conversation starter with an accompanied talk back after. Race is a sensitive subject that is riddled with bias so the conversation geared more to the informative side. Topdog/Underdog, on the other hand, tells an emotional and tragic story between two brothers. The present power struggles did not indicate who was in the "wrong" at the end. Many felt that the situation was tragic. Much to my surprise, the lasting impressions gave me permission to believe and taught me that I shouldn't discredit an audience's ability to latch on to a well written play. I got into theatre because of this notion so I can't believe I'd become jaded. My faith in the power of theatre has been restored.

\section{Final thoughts}

I thoroughly enjoyed this process. I learned why I initially felt connected to Topdog/Under. Suzan-Lori Parks declares that the black voice is unique from person to person while tying this black voice to American History. Parks choice to name her character Lincoln and Booth capitalized on the known fact that Booth kills Lincoln by relishing on the powerlessness between the two. Parks' words validated my mindset and existence making me feel complete in the process. I do not believe I need to conform to social norm portrayed in the media. Parks' play forced me to tackle some inner demons that having been plaguing me since puberty. I feel blessed to have been given the opportunity to play Booth.

It is also important to reflect on my director Jade. She served as a refuge from the rest of the program; she treated us like professional actors. Not only that, as a black director, there were some insights that she was able to help us through that I do not think would have been possible without her. This included but not limited to infusing Minstrels in our payday ritual, playing rap music during rehearsals etc. Another thing I will take way from her is when she said, "Do not 
forget about your ancestors. " Again, I've always be self-conscious about my voice so to hear that felt reassuring and heartwarming. I will never forget that.

I repeat, this show challenged me emotionally, mentally, and physically. There is no doubt about it. I had to embrace the language, the given circumstances, and the high stakes involved. When the pressures of the process became too hard, I often found solace in letting go and actively having fun. I put in the work and remained diligent with all notes given. I learned that I need to trust my resources and my process to overcome all my reservations regarding acting. This lesson alone gave me the incentive to continue to work hard during this play. Ultimately, I am proud of what came out of this process. I came to graduate school with a goal and this play put these ideas to a great test. I wanted to have vocal control and to have the capability to be vulnerable on stage. Topdog/Underdog demanded these things and I believe I rose to the challenge. I addressed issues that plagued my drive artistically and stilted my personal growth. I feel that my lasting connections with the process molded me into a confident actor. Ha! You hear that Mom? I'm a confident actor. I think I'll pat myself on the back. 


\section{Bibliography}

Brantley, Ben. "Not to Worry, Mr. Lincoln, It's Just A Con Game." The New York Times, The New York Times, 7 Apr. 2002, www.nytimes.com/2002/04/08/theater/theater-reviewnot-to-worry-mr-lincoln-it-s-just-a-con-game.html.

Delaney, Brian M. "Chekhov's Gun and Nietzsche's Hammer: The Biotechnological Revolution and the Sociology of Knowledge." Berkeley Journal of Sociology, vol. 35, 1990, pp. 167174. JSTOR, JSTOR, www.jstor.org/stable/41035505.

George-Graves, Nadine. "Basic Black.” Theatre Journal, vol. 57, no. 4, 2005, pp. 610-612. JSTOR, JSTOR, www.jstor.org/stable/25069730.

Iwamoto, Derek. "Tupac Shakur: Understanding the Identity Formation of Hyper-Masculinity of a Popular Hip-Hop Artist.” The Black Scholar, vol. 33, no. 2, 2003, pp. 44-49. JSTOR, JSTOR, www.jstor.org/stable/41069025.

Linklater, Kristin. Freeing the natural voice. Nick Hern, 2007.

McWhorter, John H. "WASTING ENERGY ON AN ILLUSION." The Black Scholar, vol. 27, no. 1, 1997, pp. 9-14. JSTOR, JSTOR, www.jstor.org/stable/41068702.

McWhorter, John H. "WASTING ENERGY ON AN ILLUSION: SIX MONTHS LATER." The Black Scholar, vol. 27, no. 2, 1997, pp. 2-5. JSTOR, JSTOR, www.jstor.org/stable/41068723.

Meisner, Sanford. On Acting. New York: Random House, Inc., 1987.

Parks, Suzan-Lori. Topdog/Underdog. Theatre Communications Group, 2014.

Shannon, Sandra. "What Is a Black Play? Tales from My Theoretical Corner." Theatre Journal, vol. 57, no. 4, 2005, pp. 603-605. JSTOR, JSTOR, www.jstor.org/stable/25069727.

Star-Ledger, Ronni Reich | The. "'Topdog/Underdog': A playwright interpreting her own words." NJ.com, 7 Sept. 2012, www.nj.com/entertainment/arts/index.ssf/2012/09/topdogunderdog_a_playwright_in.htm 1 . 